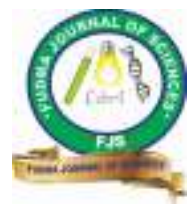

FUDMA Journal of Sciences (FJS)

ISSN online: $2616-1370$

ISSN print: 2645 - 2944

Vol. 4 No. 3, September, 2020, pp $215-223$

DOI: https://doi.org/10.33003/fjs-2020-0403-387

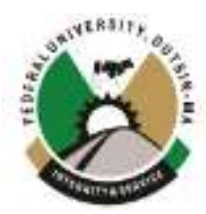

\title{
DETERMINATION OF IMMEDIATE CAUSES OF 2017 FLOOD EVENT IN DADIN KOWA TOWN, GOMBE STATE, NIGERIA
}

\author{
Saheed A. Bello, E. D Mshelia, Peter Ogoja \\ Department of Mathematics, Nassarawa State University, Keffi, Nigeria. \\ kunlebello24@gmail.com
}

\begin{abstract}
The 2017 Dadin Kowa flood had a more devastating effect in Hore Gare and Tunga areas. The flood occurred as a result of high rainfall, obstruction, siltation and encroachment into flood-prone areas. Monthly maximum and annual rainfall analyses were carried out. The month of June, 2017 received the maximum monthly rainfall of a total of $344 \mathrm{~mm}$ which coincided with the month the flood occurred. The analysis of data indicated that flooding in Dadin Kowa town is rainfall-induced and the river channels are expected to be on higher risks of flooding when the channel obstruction capacity coincides with high rainfall intensity. The mean value of annual and maximum rainfall is $834.93 \mathrm{~mm}$ and $249.08 \mathrm{~mm}$ with standard deviation of 131.95 $\mathrm{mm}$ and $49.24 \mathrm{~mm}$ respectively at Dadin Kowa town. The recurrence interval of 2, 5, 10, 25, 50, 100 and 200 years of monthly maximum rainfall is $250.70 \mathrm{~mm}, 292.80 \mathrm{~mm}, 313.00 \mathrm{~mm}, 332.70 \mathrm{~mm}, 344.30 \mathrm{~mm}, 353.90$ $\mathrm{mm}$ and $362.00 \mathrm{~mm}$ respectively. The frequency analysis of the return period of the maximum monthly rainfall of $344.00 \mathrm{~mm}$ is expected to occur in 50 years from 2018 with a magnitude of $344.30 \mathrm{~mm}$. Also, the recurrence interval of $2,5,10,25,50,100$ and 200 years of annual maximum rainfall is $838.78 \mathrm{~mm}, 949.40$ $\mathrm{mm}, 1003.60 \mathrm{~mm}, 1057.70 \mathrm{~mm}, 1090.30 \mathrm{~mm}, 1118.10 \mathrm{~mm}$ and $1142.10 \mathrm{~mm}$ respectively. The frequency analysis of the return period of the maximum annual Rainfall of $1119.30 \mathrm{~mm}$ is expected to occur in 100 years from 2018 with the magnitude of $1118.10 \mathrm{~mm}$.
\end{abstract}

Keywords: Annual rainfall, return period, obstruction, encroachment, siltation, flood frequency, Dadin Kowa Dam, flood, maximum rainfall.

\section{INTRODUCTION}

Nigeria and other countries are faced with environmental and ecological challenges particularly because of the impact of climate change. These include the occurrence of natural disasters such as fire, floods, tropical storms, major accidents, drought, epidemic diseases and food shortage (DPLG, 2007) There have been several cases of floods in Nigeria mostly resulting from heavy rainfall and excess releases from dams whose operational capacities could not cope with excessive inflows into their reservoir areas (Punch, 20th October, 2019). In most cases, these releases are made mainly to save the dams whose failure could be more catastrophic than the consequences of the releases. In all cases, houses, properties, farm produce, and animals were destroyed running into billions of naira each year (Vanguard N. , 21st September, 2005; 18th October, 2007).

Etiosa (2006) in a discussion paper on "Dams are unrenewable" reported that many settlements were flooded by the waters from Rivers Niger and Kaduna. The flood which struck on the early hours of Saturday 11th September, 2003, the heavy rainfall and the release of excess water from the Shiroro Hydro-Electric Dam by the National Electric Power Authority (NEPA) flooded over 26 villages including Galadima Kogo, Gofa, Kusasun, Pai, Lagado, Nakpinda and Karai in Kede, Lakpma and Shiroro Local Government in Niger State (Etiosa, 2006) reported by Alayande (2012). The flood displaced about 10,000 persons in Ketsho in Kede Local Government, while 13,500 others in Lakpam and Shiroro were rendered homeless. Similarly, in 1999 at least seven other districts in Local Government Areas were flooded when water from the Shiroro Dam was released. Etiosa (2006) also reported that the Obudu Dam spillway was damaged by the storm in July, 2003 which resulted in a fatal disaster that claimed over 200 houses, several farmlands, settlements and business concerns. Besides the release of excess water from Lagdo Dam, experts attributed the disaster to intensive and non-stop rainfall in Obudu on a fateful day for 16 hours (Alayande, 2012). The rainfall recorded at the Obudu Dam meteorological station was $314.5 \mathrm{~mm}$, more than 15 years average rainfall for the peak months of July and September, which was not anticipated when the dam was constructed. In a research finding on the Gusau 2006 flood event, Alayande (2012) reported that The National Water Resources Institute recorded that maximum precipitation of $182.9 \mathrm{~mm}$ was over Gusau on the $14^{\text {th }}$ August, 2006, forty-seven days before the 2006 flood which is nearer to the probable maximum precipitation of $190 \mathrm{~mm}$ calculated for the Sokoto basin, and concluded that the Gusau barrage and indeed the Sokoto river basin experienced its "limiting storm" in September, 2006 which sets in on the 14th August, 2006. However, the nonoperational status of the barrage overflow gates and the inadequate capacity of the relief spillway of $17.273 \mathrm{~m}^{3} / \mathrm{sec}$ cannot be able to cope with the incoming floodwaters into the reservoir hence the collapse of the barrage on September 30, 2006 , forty days after the basin storm sets in.

In August, 2019, residents of Lagos state lamented how the flood caused by Oyan dam releases and high rainfall cost them to abandon their properties, homes, and businesses (Punch, 20th October, 2019).

On the 6th of June, 2017, the amount of rainfall measured in Dadin Kowa by the authority was $136 \mathrm{~mm}$, the water level was $239.161 \mathrm{~m}$, the Inflow into the reservoir was $187 \mathrm{~m} / \mathrm{s}^{3}$, the total discharge was at $13.8 \mathrm{~m} / \mathrm{s}^{3}$ and the volume of the reservoir was 
at the capacity of $1,060,000,000 \mathrm{~m}^{3}$ (UBRBDA-DADIN KOWA OFFICE). On this said day, Dadin Kowa town and environs were flooded and it affected all the farmlands along the riverbank of the town.

The Gombe State Emergency Management Agency, SEMA, reported 23 persons were killed and five others missing in the Gombe flood disaster between June and July, 2017. This included six persons that were dead at Dadin Kowa on June 6; 16 died on July 1 and July 25 in Gombe town. 21 houses were destroyed by the flood. The flood also washed away a total of 119 farmlands at Jauro Baba, Jauro Mai, and Jauro Saini communities at Kamo Ward in Kaltungo Local Government of the state. Other property affected included 450 bags of grains washed away in Dadin Kowa Village and 11 bags of fertilizer in Kaltungo Local Government Area (Premium, 2017) (PropertyProInsider, 2017). The flood occurred majorly around Tunga through Gada.

The National Emergency Management Agency (NEMA) was established by Nigeria government at the Federal level and State Emergency Management Agency (SEMA) at State levels to focus on palliative measures and reducing the socioeconomic impacts of these disasters through the mobilization of relief materials to the plight of the people in the cases of disasters including flooding. Research efforts to understand the dynamics of these natural events and reducing the impacts of future flood events are receiving little attention in the country (Alayande, 2012). Flood simulations are rarely used in disaster preparations and management either at policymaking or implementation levels (Alayande, 2012).

The purpose of this study is to use descriptive statistics on rainfall data to determine the Immediate causes of 2017 flood event in Dadin Kowa town and use flood frequency analysis to determine the recurrence interval of the flood event for alertness and protection against the reoccurrence of the flood.

\section{STUDY AREA}

Dadin-Kowa town is a town in Gombe State that shares a common boundary with Akko Local Government in both the South and West, Kwami to the North and Yamatu-Deda to the East. The climate of Dadin-Kowa is characterized by a dry season of six months, alternating with a six months rainy season. As in other parts of Nigerian savanna, the precipitation distribution is mainly triggered by a seasonal shift of the intertropical Convergence Zone (ITCZ). For the years 1977 to 2018 , the mean annual precipitation is $834.93 \mathrm{~mm}$ and the mean annual temperature is about $26^{\circ} \mathrm{C}$. The relief of the town ranges between $650 \mathrm{~m}$ in the western part to $370 \mathrm{~m}$ in the eastern parts. There is a dam located in the Dadin Kowa town. The Dadin Kowa Dam is located along Gongola River in present Gombe State it flows in from Plateau Inland; it belongs to the Upper Benue River Basin Development Authority of Nigeria (As shown in Figure 1). According to Upper Benue River Basin Development Authority (1983), Dadin Kowa dam is a multipurpose earth fill dam located some $5 \mathrm{~km}$ North of Village of Dadin Kowa on river Gongola in Gombe state. The maximum flood level is $249 \mathrm{~m}$, the maximum supply level is 247 meters and the minimum supply level is 239 meters the surface area of the reservoir is $300 \mathrm{~km}^{2}$ with live storage of 1.77 billion cubic meters. The 1:10,000-year peak in-flow flood is $3,160 \mathrm{M}^{3} / \mathrm{Sec}$. and the peak outflow is $1,110 \mathrm{M}^{3} / \mathrm{Sec}$. The total catchment area of the Gongola River is approximately 56,000 square kilometers, $58.5 \%$ of which lies upstream of the dam (As illustrated in Figures 1 and 2).

The annual inflow shows that the reservoir inflow increased from May to August, after which it declined to September, with August being notably the wettest. Other months in the year never had any reasonable records of inflow over the years. This is a clear demonstration of the climatic characteristics of the reservoir catchment area. There were usually no rainfalls during those months of no inflows.

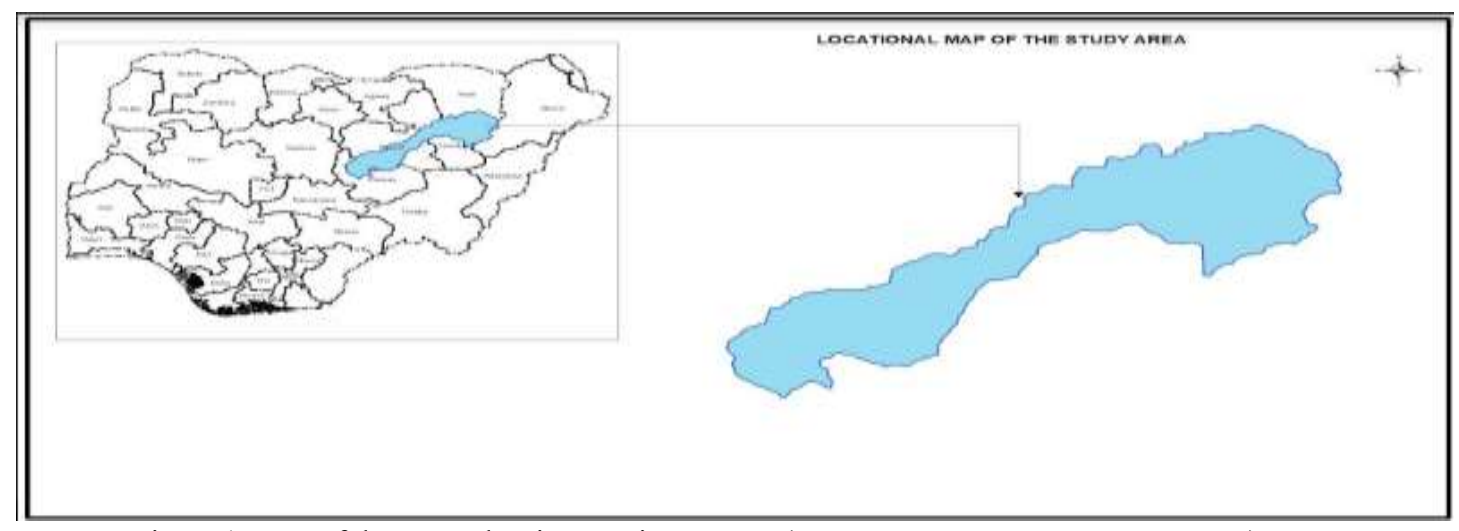

Figure 1: Map of the Gongola River Basin. Source: (UBRBDA-DADIN KOWA OFFICE) 


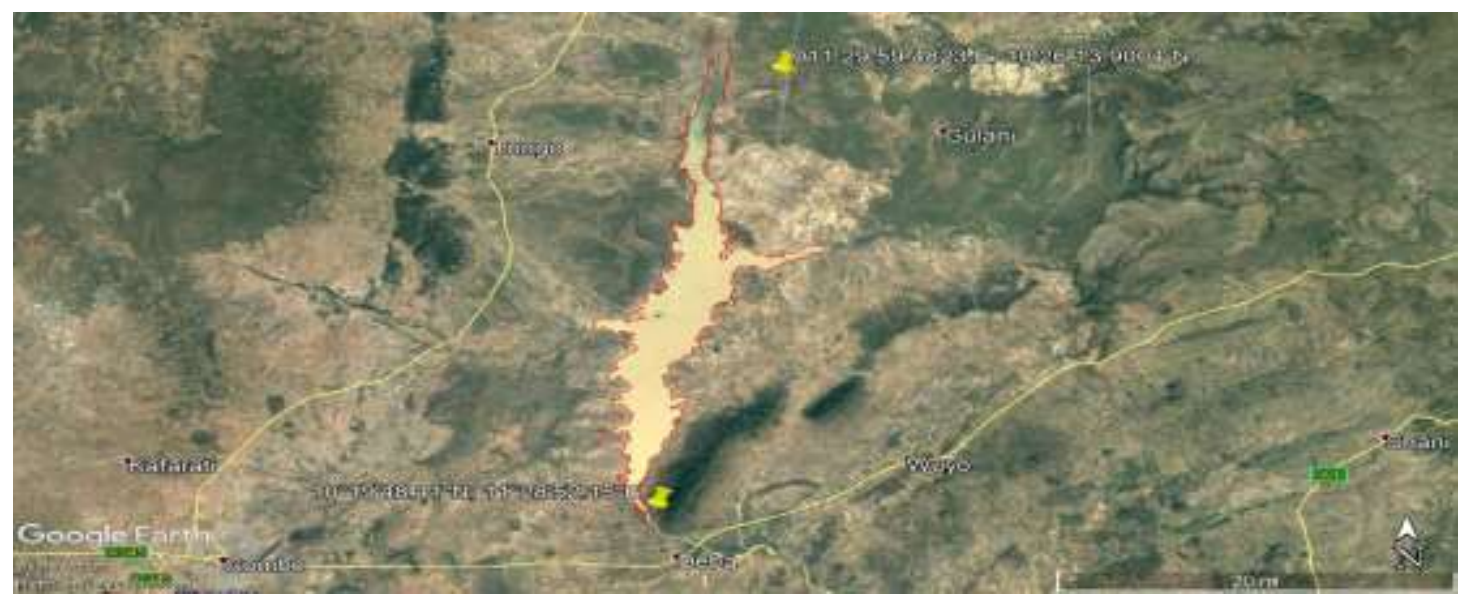

Figure 2: Dadin Kowa Dam

\section{MATERIALS AND METHODS}

\section{Rainfall Analysis}

Rainfall data for Dadin Kowa town from 1977-2018 (41 years) were collected from the Upper Benue River Basin Development Authority of Nigeria. The Upper Benue River Basin Development Authority is vested with the responsibility of documenting meteorological and climatological data in the Upper Benue River basin including Gombe State. In this study statistical tools of mean, standard deviation, maximum and minimum value were used to test for the normality in rainfall totals for the study area (Ibrahim \& Jauro, 2016).

In statistics, the sample maximum and sample minimum also called the largest observation and smallest observation respectively are the values of the greatest and the least elements of a sample. They are basic summary statistics used in descriptive statistics.

The maximum and minimum value are the first and the last order statistics denoted by $X_{n}$ and $X_{1}$ respectively, for a sample of $\mathrm{n}$

The mean $(\bar{X})$ was calculated as:

$$
\left.\begin{array}{l}
X_{1}=\min \left\{X_{1} \ldots X_{n}\right. \\
X_{n}=\max \left\{X_{1} \ldots x_{n}\right.
\end{array}\right\}
$$

$$
\bar{X}=\frac{1}{n} \sum_{i=1}^{n} X
$$

The Standard deviation $(S)$ was calculated as:

$$
S=\sqrt{\frac{1}{n-1} \sum_{i=1}^{n}(X-\bar{X})^{2}}
$$

Where $\mathrm{n}$ is the sample size and $\mathrm{X}$ is corresponding to the rainfall values

\section{Flood Frequency Analysis}

The flood frequency analysis was carried out on the rainfall database by fitting the Log Pearson Type III distribution to show the recurrence interval of the events which can be used for alertness and protection against the reoccurrence of the flood.

The Log-Pearson Type III distribution is a statistical technique for fitting frequency distribution data to predict the design flood and rainfall for a river at some site (Basumatary \& Sil, 2017) (Suhartanto, Limantara, Noviadriana, Harta, \& K, 2018). The Log-Pearson Type III distribution is calculated using the general equation:

$$
X=\bar{X}+K S
$$$$
5
$$

where $X$ is the $\log$ of rainfall values of some specified probability, $\bar{X}$ is the average of the $\log X$ values, $K$ is a frequency factor, and $S$ is the standard deviation of the $\log X$ values. The frequency factor $K$ is a function of the skewness coefficient and return period and can be found using the frequency table. The flood magnitudes for the various return periods were found by solving the general equation 5 on
Microsoft EXCEL.

The basic objective of frequency analysis is to determine the rainfall values for $200,100,50,20,10,5$ and 2 years annual reoccurrence. The following steps will be taken:

- $\quad$ Ranking the historic data and assign the plotting position by estimating the probability of exceedance;

- $\quad$ Estimate the Pearson Type III distribution function and plotting the data on a probability sheet;

- $\quad$ Determining the data depths that can be expected for the selected return period $(200,100,50,20,10,5$ and 2 years).

\section{RESULTS AND DISCUSSION \\ Rainfall Analysis}

Rainfall is an important factor when it comes to flooding. The magnitude of rainfall affects the characteristics of a basin when it rains, which in turn affects the inflow and discharge of a reservoir. Statistical approaches of analyzing the extreme rainfall effect in the catchment were carried out especially to determine the causes of flood on the 7th of June, 2017. 
Table 1: Descriptive Statistics of Monthly and Annual Rainfall of Dadin Kowa, 1977-2018. (UBRBDA-DADIN KOWA

\begin{tabular}{|c|c|c|c|c|c|}
\hline \multicolumn{6}{|c|}{ OFFICE) } \\
\hline & ANNUAL & & & & \\
\hline YEAR & TOTAL (mm) & $\begin{array}{c}\text { Monthly Max } \\
(\mathrm{mm})\end{array}$ & $\begin{array}{c}\text { Monthly Max. } \\
\text { Month }\end{array}$ & $\begin{array}{c}\text { Monthly Min. } \\
\text { (mm) }\end{array}$ & $\begin{array}{c}\text { Monthly Min. } \\
\text { Month }\end{array}$ \\
\hline 1977 & 806.80 & 319.00 & August & 33.00 & May \\
\hline 1978 & 821.60 & 245.60 & July & 23.60 & October \\
\hline 1979 & 674.50 & 188.00 & August & 7.90 & April \\
\hline 1980 & 886.70 & 263.90 & July & 25.40 & April \\
\hline 1981 & 741.80 & 233.40 & July & 41.10 & April \\
\hline 1982 & 792.10 & 161.30 & August & 26.50 & April \\
\hline 1983 & 695.40 & 227.80 & September & 37.50 & May \\
\hline 1984 & 865.90 & 194.30 & August & 18.00 & October \\
\hline 1985 & 683.40 & 214.70 & July & 12.30 & March \\
\hline 1986 & 702.70 & 164.80 & July & 1.00 & November \\
\hline 1987 & 506.30 & 141.30 & September & 2.70 & April \\
\hline 1988 & 956.10 & 303.90 & August & 27.00 & April \\
\hline 1989 & 833.00 & 277.10 & August & 2.30 & April \\
\hline 1990 & 599.40 & 160.40 & September & 15.50 & April \\
\hline 1991 & 855.90 & 199.20 & July & 12.10 & March \\
\hline 1992 & 750.30 & 264.50 & July & 1.60 & March \\
\hline 1993 & 659.10 & 182.50 & August & 29.90 & October \\
\hline 1994 & 887.50 & 285.50 & August & 28.00 & October \\
\hline 1995 & 790.70 & 236.60 & July & 1.00 & March \\
\hline 1996 & 945.70 & 262.80 & June & 4.10 & April \\
\hline 1997 & 928.60 & 229.70 & March & 41.50 & October \\
\hline 1998 & 828.80 & 192.80 & July & 0.20 & April \\
\hline 1999 & 857.90 & 264.30 & August & 44.40 & April \\
\hline 2000 & 1119.30 & 264.80 & September & 14.00 & October \\
\hline 2001 & 798.90 & 229.50 & September & 14.00 & October \\
\hline 2002 & 793.00 & 287.20 & August & 11.20 & May \\
\hline 2003 & 998.80 & 327.10 & July & 21.00 & April \\
\hline 2004 & 900.80 & 297.30 & August & 9.30 & October \\
\hline 2005 & 938.50 & 281.40 & July & 11.30 & April \\
\hline 2006 & 964.80 & 270.30 & July & 28.40 & April \\
\hline 2007 & 929.40 & 290.70 & July & 25.70 & October \\
\hline 2008 & 1074.30 & 279.30 & August & 88.50 & April \\
\hline 2009 & 1055.00 & 299.00 & June & 55.40 & May \\
\hline 2010 & 897.30 & 230.20 & July & 41.70 & April \\
\hline 2011 & 731.50 & 199.10 & July & 1.30 & April \\
\hline 2012 & 1022.80 & 284.10 & July & 21.80 & April \\
\hline 2013 & 724.80 & 309.80 & September & 1.80 & April \\
\hline 2014 & 881.20 & 253.30 & August & 21.60 & October \\
\hline 2015 & 849.10 & 282.80 & August & 59.70 & June \\
\hline 2016 & 624.30 & 289.30 & August & 23.50 & October \\
\hline 2017 & 890.00 & 334.00 & June & 25.80 & April \\
\hline 2018 & 803.20 & 237.70 & August & 16.70 & April \\
\hline Mean & 834.93 & 249.05 & & 22.09 & \\
\hline Maximum & 1119.30 & 334.00 & & 88.50 & \\
\hline Minimum & 506.30 & 141.30 & & 0.20 & \\
\hline S/Deviation & 131.95 & 49.24 & & 18.62 & \\
\hline
\end{tabular}

The analysis was carried out on Word Excel. The following b. Annual total Rainfall

database of extreme rainfall events was generated from available rainfall data at Dadin Kowa Dam (Akinsanola \& Ogunjobi, 2014) (Ibrahim \& Jauro, 2016):

a. Monthly Maximum rainfall;

\section{Monthly Rainfall}

The Monthly rainfall total reaches their maximum between March and September as presented in Table 1. The monthly 
rainfall data measured at Dadin Kowa town for each month of the year 1977 to 2018 were computed as shown in Table 1 and Figure 3, and the maximum rainfall of $344 \mathrm{~mm}$ was recorded in June, 2017, follows by $327.10 \mathrm{~mm}$ in July, 2003, the third maximum rainfall occurred in August, 1977 with $319.00 \mathrm{~mm}$ and the fourth and fifth maximum rainfall were $309 \mathrm{~mm}$ and $303 \mathrm{~mm}$ in September and August of the year 2013 and 1988 respectively. It is clear from these results that rainfall yield is increasing in the study area (As shown in Figure 3). The increase does not show a distinct trend because there are fluctuations. This result seems to be in good agreement with the study of Yahaya (2015) and Ibrahim \& Jauro (2016) that state that the rainfall yield is increasing in the North-East of Nigeria. The maximum rainfall of $344 \mathrm{~mm}$ coincides with June, 2017 in which flood occurred in the town. The implications of this show that the flood was rainfall-induced.

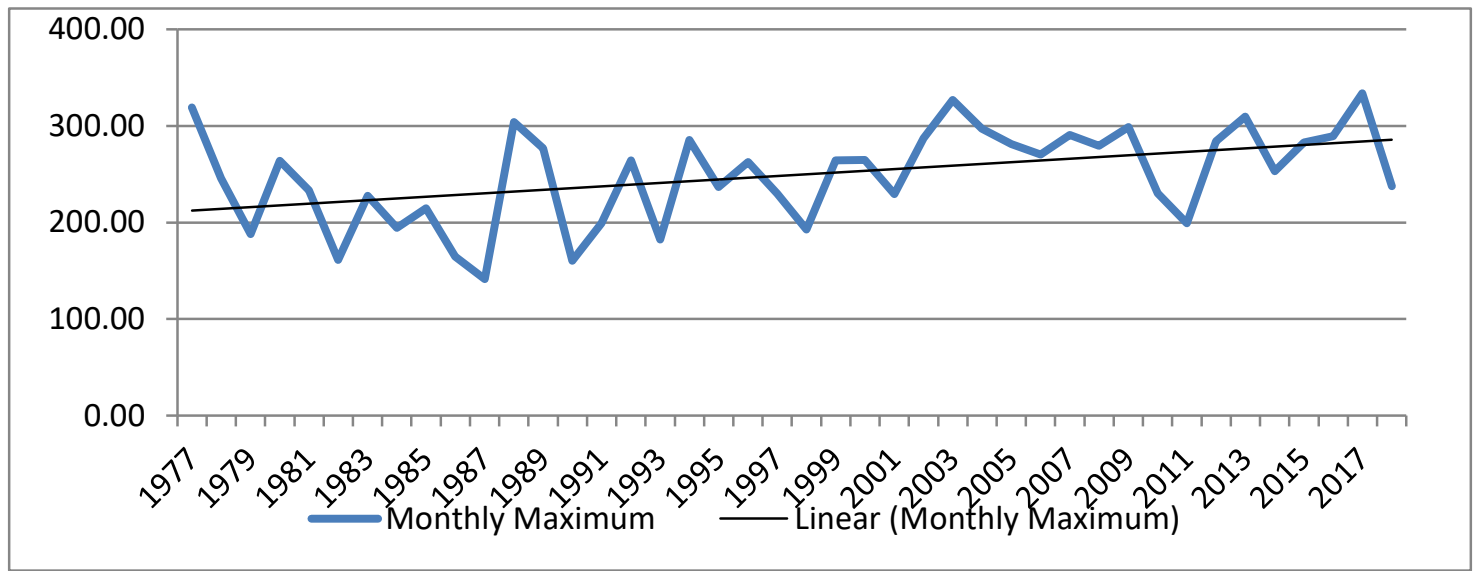

Figure 3: Monthly Max Rainfall of Dadin-Kowa reservoir basin 1977-2018 (UBRBDA-DADIN KOWA OFFICE).

\section{Annual Rainfall}

From Table 1 and Figure 4, the total annual rainfall measured at Dadin Kowa dam for the period 1977 to 2018 indicated the year 2000 annual rainfall of $1119.30 \mathrm{~mm}$ was the highest historical maximum annual rainfall following $1074.30 \mathrm{~mm}$ in 2008 , and the third and fourth maximum annual rainfall was $1055 \mathrm{~mm}$ and $1022 \mathrm{~mm}$ in 2009 and 2012 respectively. The maximum annual rainfall of 2017 flood was the $14^{\text {th }}$ maximum annual rainfall between 1977 and 2018. There was no information that the Dadin Kowa town got flooded in 2000,
2008, 2009, 2012, 2003, 2006, 1988, 1996, 2005, 2007, 1997, 2004 and 2010 which have a higher maximum annual rainfall than 2017. But the level of urbanization and hence encroachment into the floodplain is higher in 2017 than in any of the years 2000, 2008, 2009, 2012, 2003, 2006, 1988, 1996, 2005, 2007, 1997, 2004 and 2010. The graphical presentations of the rainfall analysis as presented in Figure 5, indicated an upward trend in annual rainfall. This further explains that the 2017 flood was as a result of peak rainfall and encroachment into the floodplain areas as shown in Figures 6 a-b.

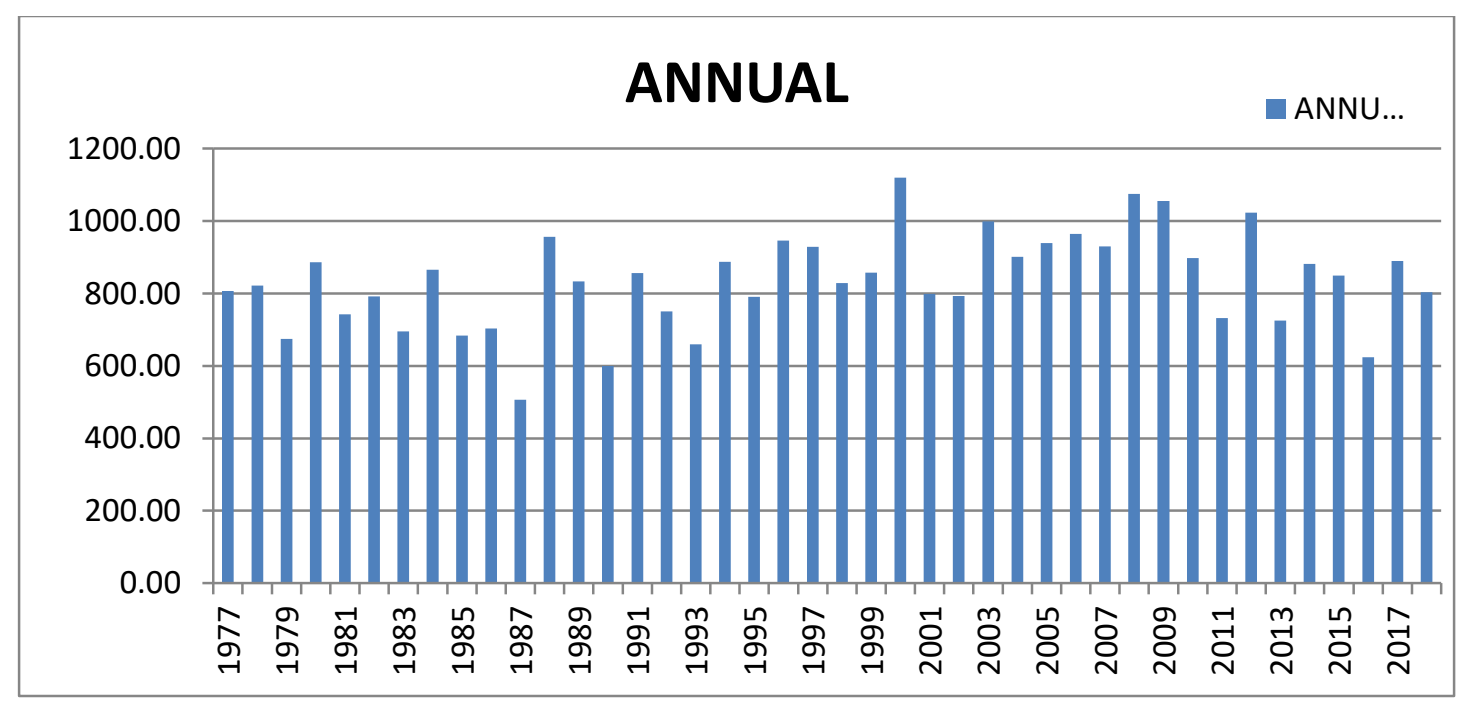

FUDMA Journal of Sciences (FJS) Vol. 4 No. 3, September, 2020, pp 215 - 223 
Figure 4: Annual rainfall of Dadin Kowa Dam between the years 1977 - 2018

(UBRBDA-DADIN KOWA OFFICE)

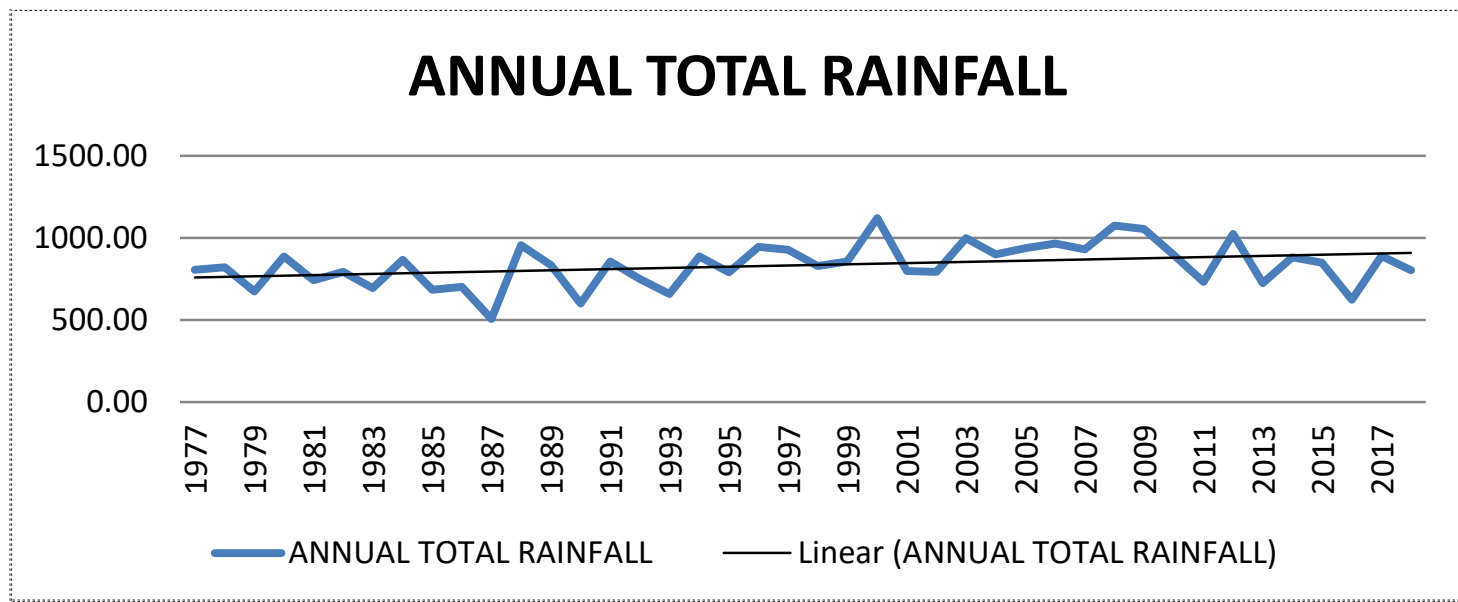

Figure 5: Total annual Rainfall of Dadin-Kowa Reservoir Basin between 1977-2018

(UBRBDA-DADIN KOWA OFFICE)

from the dam.

River Nunu flows from Hore Gare into Gongola River through

River Yelwa passes through Gada Dauda in the heart of Tunga, it flows into River Gongola at the downstream of Dadin Kowa. As shown in Figure 7, the level of siltation in the river channel is high and almost silted up, the river met obstruction at the junction (As shown in Figure 8) and then flows back into the town at the hour of the flood due to high rainfall and releases an irrigation site in Tunga. The river Nunu (As illustrated in Figure 9) is almost silted up and during the 2017 flood due to high rainfall and releases from Dadin Kowa Dam it overflows and got flooded around $60 \%$ of irrigation sites both in faces 1 and 2. Also, the Hore Gare village was flooded.
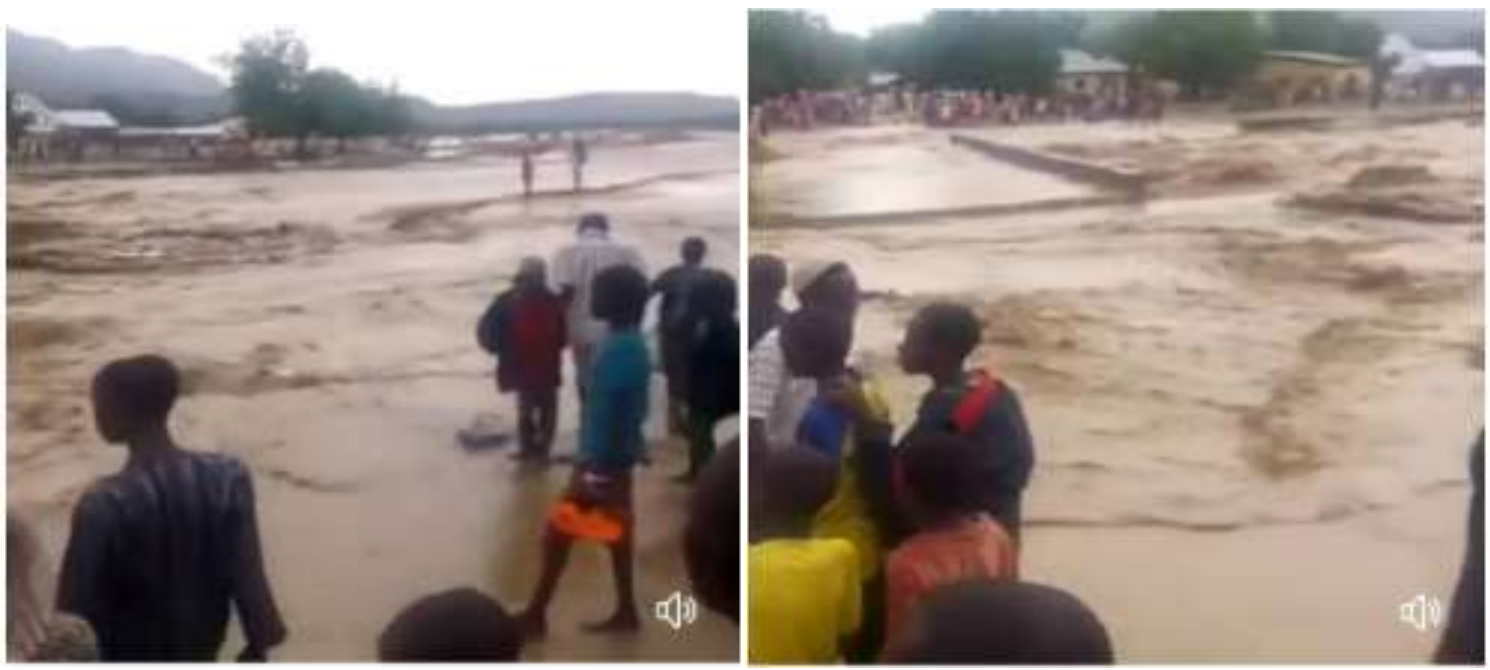

Figure 6a: Overflew Gada Dauda during the 2017 Dadin Kowa flood 


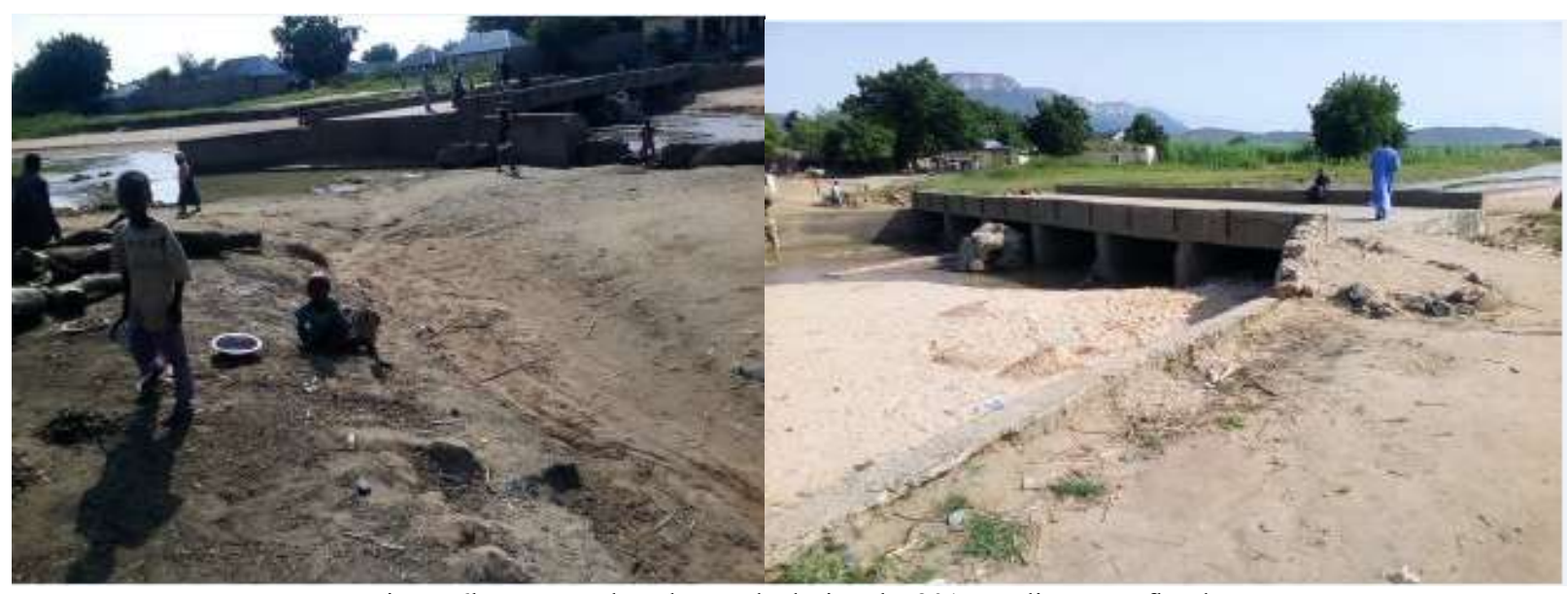

Figure 6b: Damaged Gada Dauda during the 2017 Dadin Kowa flood

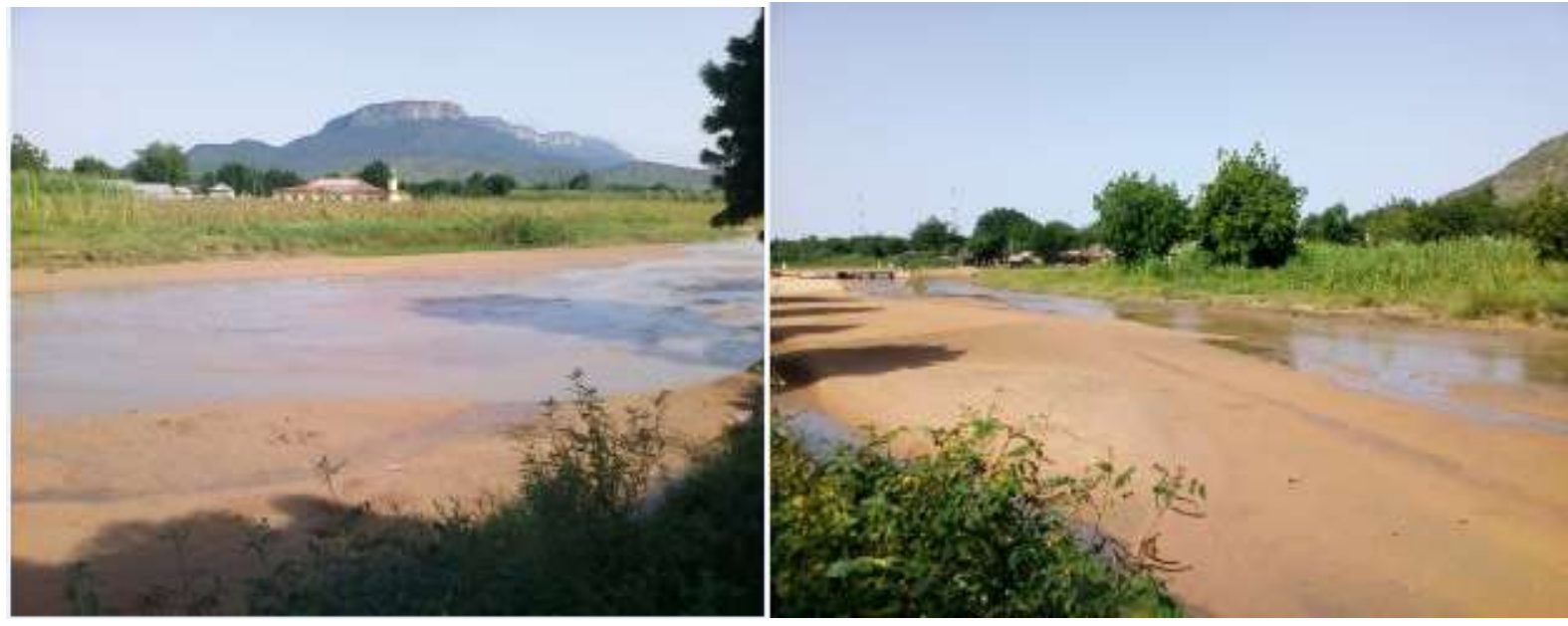

Figure 7: River Yelwa and encroachment Area in the Flood prone

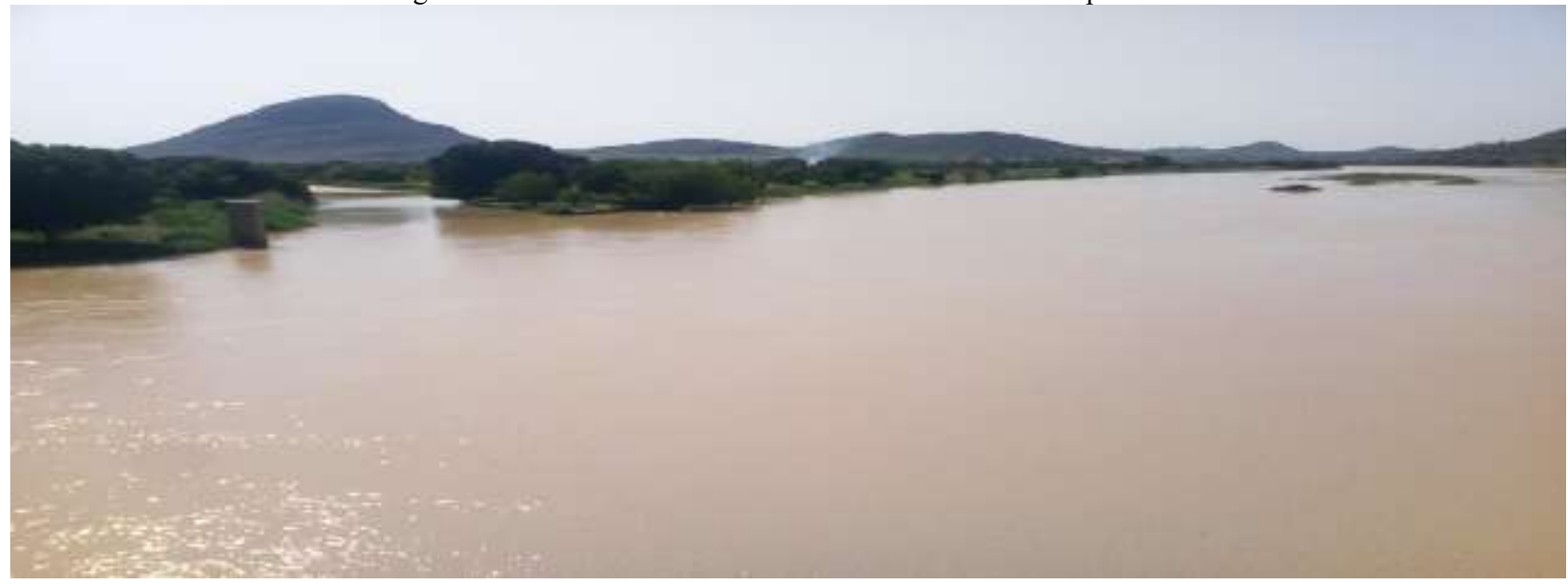

Figure 8: Junction of River Yelwa and Gongola River 


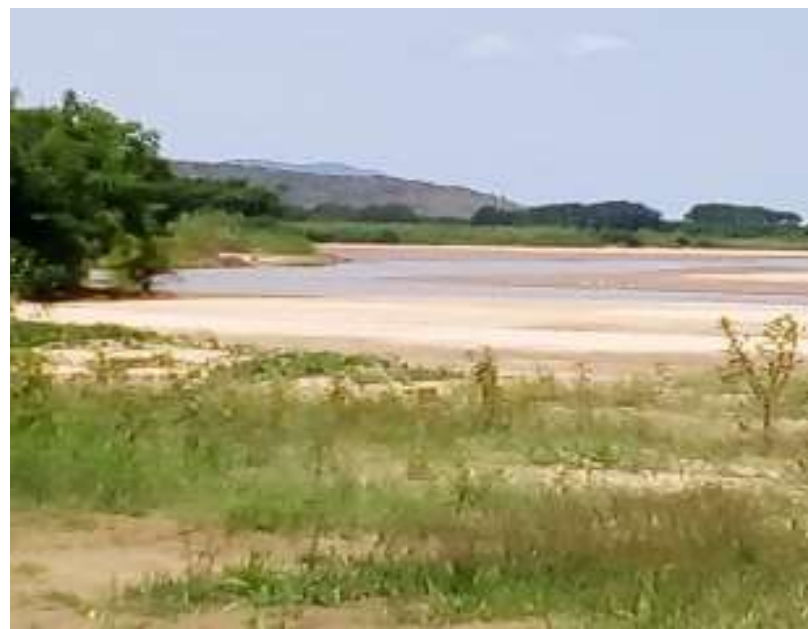

Figure 9: River $\mathrm{NuNu}$

The analysis of the Rainfall data indicated that the flooding in 2017 in Dadin Kowa was caused by high rainfall, encroachment into flood-prone areas, siltation, and obstruction which coincides with high rainfall.

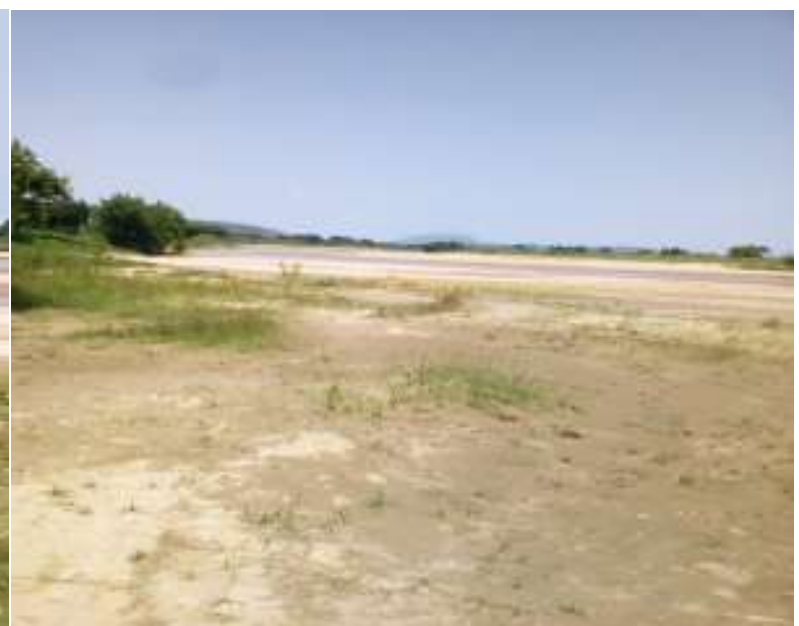

The rainfall magnitudes for the various return periods were found by solving the Log Pearson Type III distribution equation on Microsoft EXCEL. The analysis results are presented in Table 2 and Figure 10.

Table 2: Frequency Analysis of Rainfall at Dadin Kowa town

\begin{tabular}{|l|l|l|l|l|l|l|l|}
\hline & \multicolumn{7}{|l|}{} \\
\hline Year(period) & 2 & 5 & 10 & 25 & 50 & 100 & 200 \\
\hline $\begin{array}{l}\text { Annual Rainfall } \\
\text { (mm) }\end{array}$ & 838.78 & 949.40 & 1003.60 & 1057.70 & 1090.3 & 1118.10 & 1142.10 \\
\hline $\begin{array}{l}\text { Monthly Max } \\
\text { Rainfall (mm) }\end{array}$ & 250.70 & 292.80 & 313.00 & 332.70 & 344.30 & 353.90 & 362.00 \\
\hline
\end{tabular}

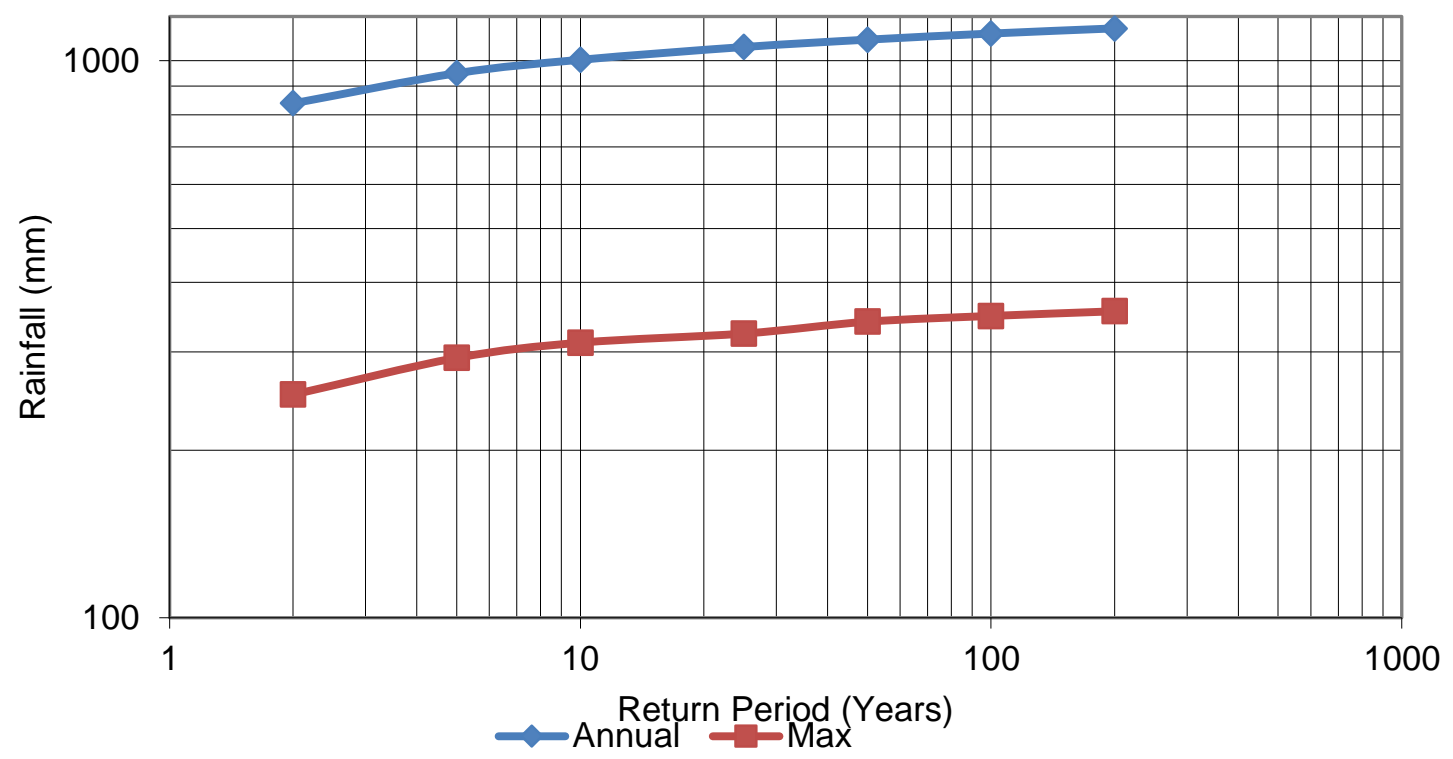

Figure 10: Flood Frequency Analysis for Dadin Kowa using Log-Pearson Type III Analysis using Annual Rainfall Values (19772018)

From Table 1, the mean value of annual and maximum rainfall of monthly maximum rainfall in Dadin Kowa is $250.70 \mathrm{~mm}$, is $834.93 \mathrm{~mm}$ and $249.08 \mathrm{~mm}$ with standard deviation of $292.80 \mathrm{~mm}, 313.00 \mathrm{~mm}, 332.70 \mathrm{~mm}, 344.30 \mathrm{~mm}, 353.90 \mathrm{~mm}$ $131.95 \mathrm{~mm}$ and $49.24 \mathrm{~mm}$ respectively at Dadin Kowa town. and $362.00 \mathrm{~mm}$ respectively as shown from Table 2 and Figure For a recurrence interval of 2, 5, 10, 25, 50, 100 and 200 years 10. The frequency analysis as presented from table 2 showed 
the return period of the maximum monthly Rainfall of 344.00 $\mathrm{mm}$ is expected to occur in 50 years from 2018 with a magnitude of $344.30 \mathrm{~mm}$. Also, for a recurrence interval of 2, $5,10,25,50,100$ and 200 years of annual maximum rainfall in Dadin Kowa is $838.78 \mathrm{~mm}, 949.40 \mathrm{~mm}, 1003.60 \mathrm{~mm}, 1057.70$ $\mathrm{mm}, 1090.30 \mathrm{~mm}, 1118.10 \mathrm{~mm}$ and $1142.10 \mathrm{~mm}$ respectively. The frequency analysis as presented from Table 2 showed the return period of the maximum annual Rainfall of $1119.30 \mathrm{~mm}$ is expected to occur in 100 years from 2018 with the magnitude of $1118.10 \mathrm{~mm}$.

The results can be used to prepare and prevent the future occurrence of the 2017 flood event in Dadin Kowa.

\section{CONCLUSION}

The analysis of the rainfall data through the descriptive statistics indicated that the flooding in 2017 in Dadin Kowa was caused by high rainfall, encroachment into flood-prone areas, siltation and obstruction created by the releases from the Dam. The flood frequency analysis carried out on the rainfall database by fitting the Log Pearson Type III distribution showed the return period of the maximum monthly Rainfall is in 50 years from the year 2018 with the magnitude of 344.30 $\mathrm{mm}$. And the return period for the maximum annual Rainfall is in 100 years from 2018 with the magnitude of $1118.10 \mathrm{~mm}$. These results can be used to prepare and prevent the future occurrence of the flood.

Evacuating people from the floodplain and dredging of the river Yelwa and River Nunu should be done to prevent future occurrence of flood events.

\section{ACKNOWLEDGEMENTS}

The authors would like to thank the Upper Benue River Development Authority for providing the rainfall depths data in this study.

\section{REFERENCES}

Akinsanola, A., \& Ogunjobi, O. (2014). Analysis of Rainfall and Temperature Variability Over Nigeria. Global Journals Inc., Volume 14 Issue 3 Version 1.0.

Alayande, A. W. (2012). Impacts of Urbanization on Kaduna River Flooding and Streamflow Modeling. Ph.D. Thesis. Basumatary, V., \& Sil, B. S. (2017). Generation of Rainfall Intensity-Duration-Frequency curves for the Barak River Basin. Meteorology, Hydrology and Water Management Research and Operational Applications., Volume 6.

DPLG (2006/2007). Inaugural annual report. The report, National Disaster Management Centre, Department of Provincial and Local Government. http://www.info.gov.za/view/DownloadFileAction?id=85534 018).
Etiosa, U. (2006). Dams are Unrenewable. A Discussion Paper on Community Research and Development center. Community Research and Development center.

Ibrahim, Y., \& Jauro, A. S. (2016). Statistical Study of Rainfall Pattern in Gombe Metropolis, and its Implication on the Attainment of Sustainable Development Goals (SDGs). International Journal of Scientific and Research Publications, Volume 6, Issue 6, ISSN 2250-3153.

Punch. (2019). Residents use canoe as flood takes over Lagos Community. Daily Newspaper.

Suhartanto, E., Limantara, L. M., Noviadriana, D., Harta, F. I., \& K, D. A. (2018). Estimation of Design Flood with Four Frequency Analysis Distributions. Asian Journal of Applied Science and Technology (AJAST), Volume 2, Issue 1, Pages 13-27.

UBRBDA-DADIN KOWA OFFICE. (n.d.). Upper Benue River Basin Development Authority.

Upper Benue River Basin Development Authority. (1983). Newsletter.

Vanguard. (2007). Ogun Government needs N6 billion to repair damaged infrastructures. Vanguard Newspapers, 9.

Vanguard, N. (2005; 2007). Flood Submerges 5,508 houses in eight Local Government in Bauchi. Vanguard Newspaper, 12.

Yahaya, I (2015). Analysis of Rainfall Variability in NorthEastern Nigeria. M.sc Thesis. 